\title{
Coiled-Coils at the Edge of Configurational Heterogeneity. Structural Analyses of Parallel and Antiparallel Homotetrameric Coiled-Coils Reveal Configurational Sensitivity to a Single Solvent-Exposed Amino Acid Substitution.
}

\author{
Maneesh K. Yadav , Luke J. Leman ${ }^{\ddagger}$ Daniel J. Price, Charles L. Brooks III, C. David Stout, M. Reza \\ Ghadiri* \\ Departments of Chemistry, Molecular Biology, and The Skaggs Institute of Chemical Biology, The Scripps Research Institute, \\ 10550 North Torrey Pines Road, La Jolla, California 92037 \\ \$ These authors contributed equally to this study. \\ * Address correspondence to this author. (858) 784-2700 (phone); (858) 784-2798 (fax); ghadiri@scripps.edu (e-mail).
}

Table S1. Crystallization Statistics. ${ }^{a}$

\begin{tabular}{|c|c|c|c|c|c|c|c|c|c|c|c|c|}
\hline Peptide & Edge Lengths $(\AA)$ & $\begin{array}{l}d_{\max } \\
(\AA) \\
\end{array}$ & $\begin{array}{l}d_{\min } \\
(\AA) \\
\end{array}$ & $\mathrm{N}_{\mathrm{obs}}$ & $\mathrm{N}_{\text {unique }}$ & $\begin{array}{c}\mathrm{I} / \sigma \\
{[\mathrm{avg}]}\end{array}$ & $\begin{array}{c}\mathrm{I} / \sigma \\
\text { [outer] }\end{array}$ & $\begin{array}{l}\mathrm{R}_{\text {sym }} \\
(\%) \\
\end{array}$ & $\begin{array}{c}\mathrm{R} \\
(\%) \\
\end{array}$ & $\begin{array}{c}\mathrm{R}_{5 \% \text { free }} \\
(\%)\end{array}$ & $\begin{array}{c}\text { PDB } \\
\text { ID }\end{array}$ & $\begin{array}{c}\text { Configu- } \\
\text { ration }\end{array}$ \\
\hline \multicolumn{13}{|c|}{ Cubic $(P 4,132)$} \\
\hline E20S (4) & $\begin{array}{lll}79.99 & 79.99 & 79.99\end{array}$ & 56.52 & 1.9 & 77762 & 6759 & 20.6 & 2.4 & 6.2 & 28 & 32 & $2 \mathrm{CCE}$ & Para \\
\hline $\begin{array}{l}\text { ABA-pLI } \\
\text { (5) }\end{array}$ & $\begin{array}{lll}79.22 & 79.22 & 79.22\end{array}$ & 35.43 & 2.3 & 21324 & 3949 & 6.1 & 2.4 & 6.9 & 23 & 29 & $1 \mathrm{~W} 5 \mathrm{I}$ & Para \\
\hline $\begin{array}{l}\text { E20C } \\
\text { L16G }(\mathbf{9})^{b}\end{array}$ & $\begin{array}{lll}78.4 & 78.4 & 78.4\end{array}$ & 55.05 & 2.1 & 35342 & 4747 & 5.7 & 1.9 & 7.8 & 27 & 29 & $1 \mathrm{~W} 5 \mathrm{~L}$ & Para \\
\hline \multicolumn{13}{|c|}{ Orthorhombic $\left(P 2_{1} \underline{2}_{1} \underline{2}\right)$} \\
\hline 2 & $\begin{array}{lll}33.88 & 37.31 & 104.10\end{array}$ & 37.31 & 1.9 & 52270 & 10526 & 9.4 & 2.3 & 5.4 & 25 & 30 & $1 \mathrm{~W} 5 \mathrm{~K}$ & Anti \\
\hline $2^{\mathrm{Se}}$ & $\begin{array}{lll}33.81 & 37.38 & 104.42\end{array}$ & 37.38 & 1.9 & 141273 & 9988 & 7.3 & 2.4 & 6.1 & $\sim$ & $\sim$ & $\sim$ & Anti \\
\hline $\begin{array}{l}\mathbf{2}^{\text {se }}, \mathrm{Au} \\
\text { soak }\end{array}$ & $\begin{array}{lll}34.11 & 37.29 & 104.86\end{array}$ & 37.29 & 1.9 & 114206 & 11118 & 5.3 & 1.3 & 9.2 & $\sim$ & $\sim$ & $\sim$ & Anti \\
\hline 6 & $\begin{array}{lll}33.69 & 37.19 & 103.99\end{array}$ & 52 & 2.2 & 29539 & 7065 & 5.3 & 2.6 & 7.2 & 23 & 29 & $1 \mathrm{~W} 5 \mathrm{~J}$ & Anti \\
\hline \multicolumn{13}{|c|}{$\underline{\text { Tetragonal }\left(P 4_{2} \underline{2}_{1} \underline{2}\right)}$} \\
\hline E20C (3) & $\begin{array}{llll}35.38 & 35.38 & 104.31\end{array}$ & 34.77 & 1.6 & 50098 & 9398 & 11.4 & 2.4 & 3.2 & 22 & 26 & $2 \mathrm{CCN}$ & Anti \\
\hline E20S (4) & $\begin{array}{lll}35.39 & 35.39 & 104.23\end{array}$ & 52.13 & 1.7 & 62984 & 7379 & 24.4 & 2.0 & 5.5 & 24 & 32 & $2 \mathrm{CCF}$ & Anti \\
\hline $\begin{array}{l}\text { E20C } \\
\text { Y17H (7) }\end{array}$ & $\begin{array}{lll}35.41 & 35.41 & 104.97\end{array}$ & 35.41 & 2.2 & 27126 & 3816 & 6.8 & 2 & 5.2 & 28 & 34 & $1 \mathrm{~W} 5 \mathrm{H}$ & Anti \\
\hline $\begin{array}{l}E 20 C^{A K} \\
(8)\end{array}$ & $\begin{array}{llll}35.23 & 35.23 & 104.64\end{array}$ & 34.88 & 2.2 & 21443 & 3846 & 7.4 & 3 & 5.2 & 30 & 34 & $1 \mathrm{~W} 5 \mathrm{G}$ & Anti \\
\hline \multicolumn{13}{|c|}{$\underline{\text { Trigonal }\left(P 3_{1}\right)}$} \\
\hline $\begin{array}{l}\text { E20C } \\
\text { L16G } \\
\text { Y17H } \\
(\mathbf{1 0})^{b}\end{array}$ & $\begin{array}{lll}25.8 & 25.8 & 148.6\end{array}$ & 149.1 & 1.5 & 89229 & 17250 & 25.7 & 4.7 & 6.8 & 24 & 28 & $2 \mathrm{BNI}$ & Anti \\
\hline
\end{tabular}


a)

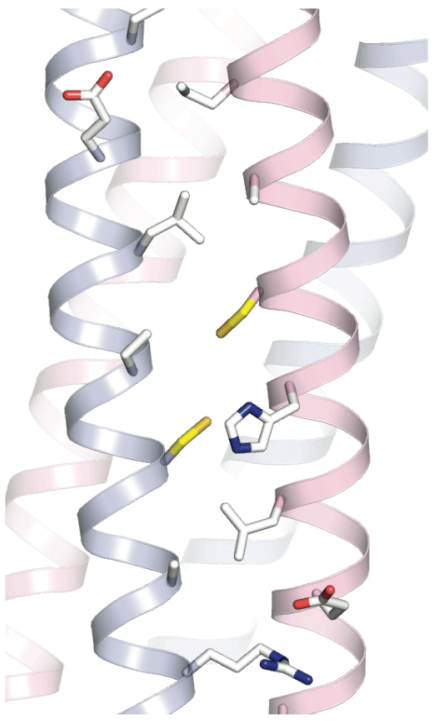

peptide 2 antiparallel, C20 face b)

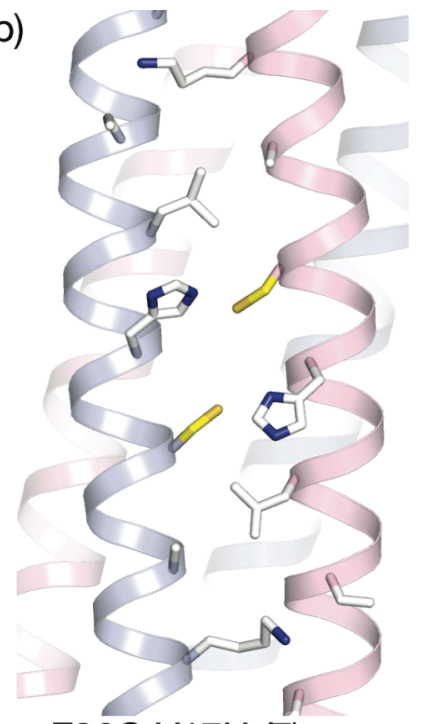

E20C Y17H (7) antiparallel, C20 face c)

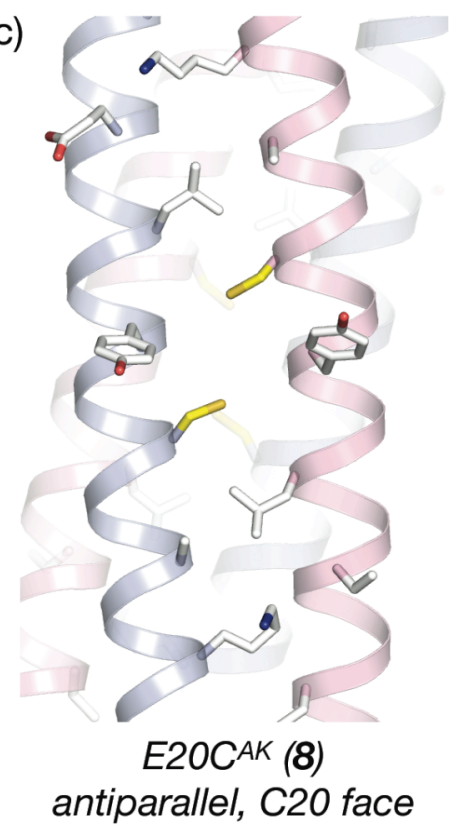

d)

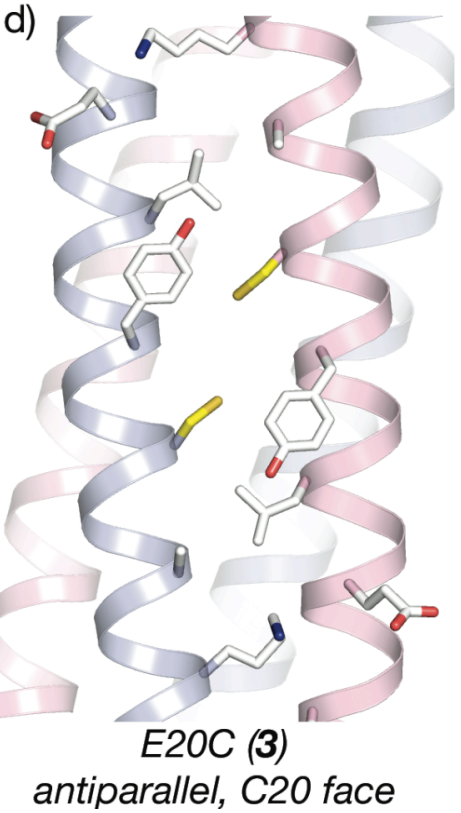

e)

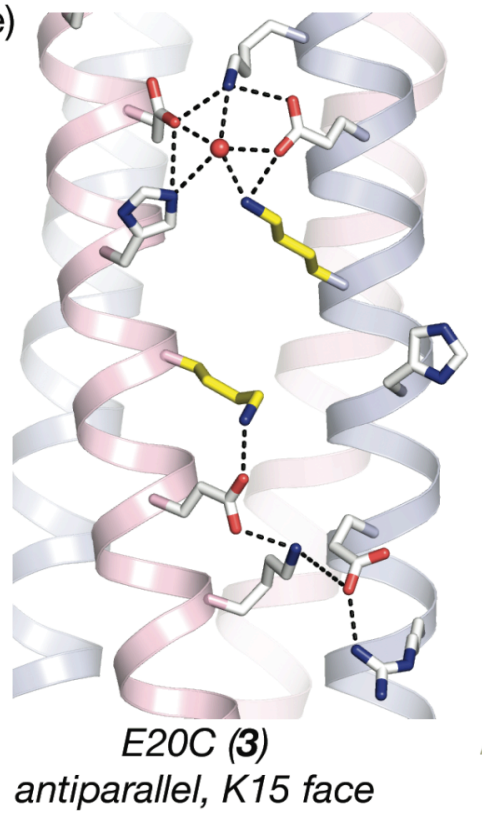

f)

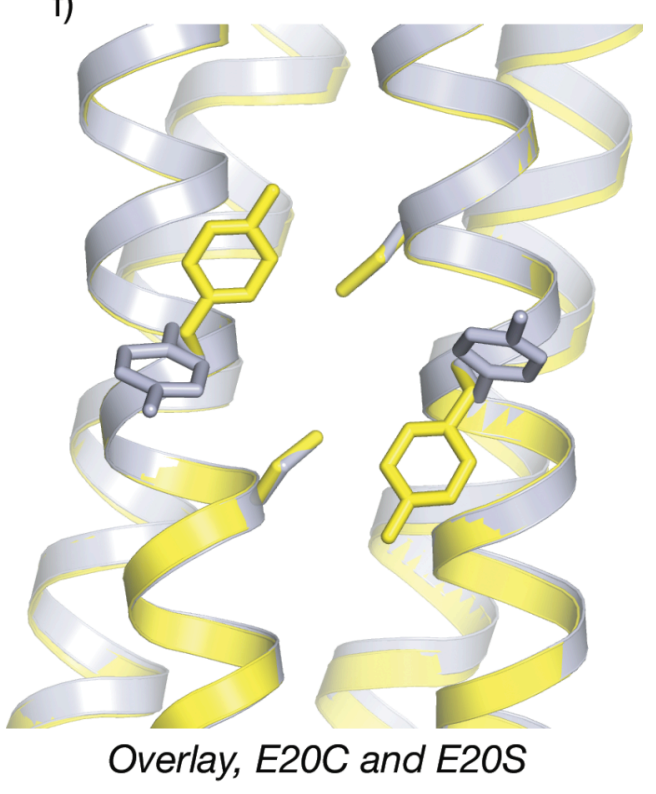

Figure S1. Comparison of surface residue conformations in the antiparallel homotetramers. The Cys 20 face is shown for a) peptide 2, b) E20C Y17H, c) E20C ${ }^{A K}$, and d) E20C. In all cases, Cys20 is depicted as yellow sticks and other solvent-exposed residues are shown as white sticks. Although the acetamide thioether was not resolved in the structure of peptide $\mathbf{8}$ (panel c), the nearby Tyr17 residues rotate relative to their positions in the non-alkylated peptide 3 (panel d). Apart from the Tyr or His residues at position 17, side chain conformations are quite similar across all the structures. e) The solvent-exposed residues on the Lys15 face of E20C (sequence 3) exhibit similar conformations to those of GCN4-pLI and E20S (see Figure 3 of the manuscript). f) An overlay of the antiparallel E20S structure (peptide 4) and the antiparallel E20C structure (peptide 3) with stick representations shown for Cys20/Ser20 and Tyr17. In the E20S structure (gray), Tyr17 is projected away from the peptide backbone and interacts with structured water molecules, while in E20C (yellow) the Tyr residues pack against the helix interface, possibly due to the increased hydrophobicity of Cys relative to Ser. 


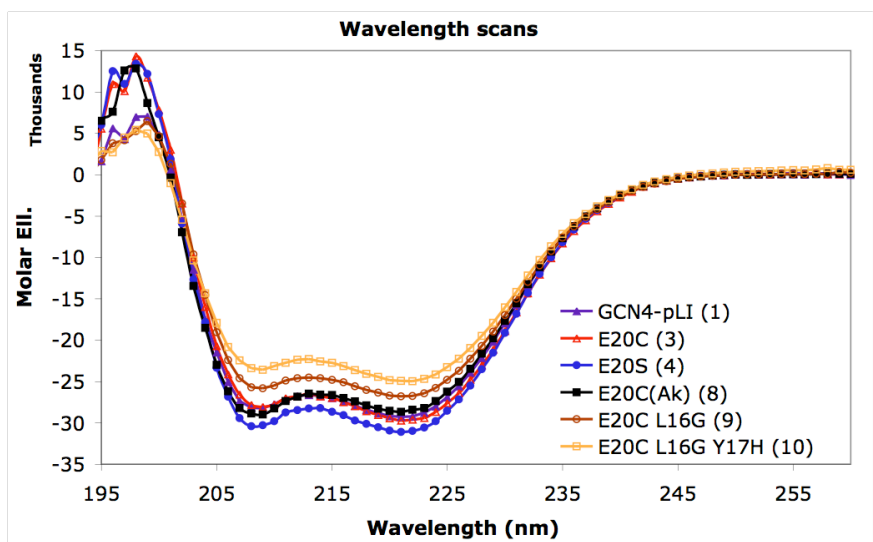

Figure S2. Circular dichroism wavelength scans for selected peptides. All samples contained peptide (20 $\mu \mathrm{M}$ ) in buffer (5 mM MOPS, $\mathrm{pH} 7.0$ ). Samples for peptides with free Cys residues also contained $0.5 \mathrm{mM}$ dithiothreitol as reducing agent.

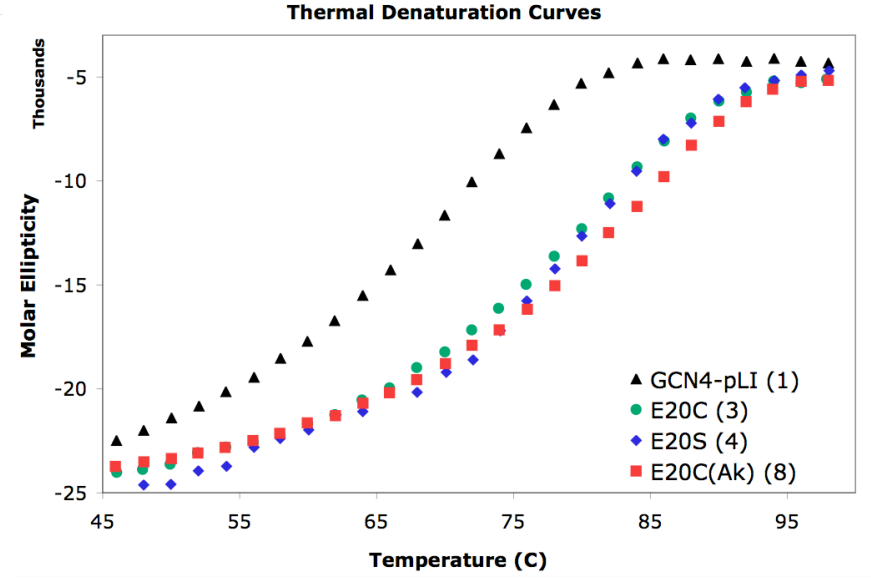

Figure S3. Thermal denaturation curves (as determined by circular dichroism) for selected peptides. All samples contained peptide $(10 \mu \mathrm{M})$ in buffer $(50 \mathrm{mM}$ phosphate, $\mathrm{pH} 7.0,150 \mathrm{mM} \mathrm{NaCl}, 4.0 \mathrm{M}$ guanidinium hydrochloride). The E20C sample also contained 0.5 $\mathrm{mM}$ dithiothreitol as reducing agent.

Supporting References:

S1. Yadav, M. K., Redman, J. E., Leman, L. J., Alvarez-Gutierrez, J. M., Zhang, Y., Stout, C. D., and Ghadiri, M. R. (2005) Structure-Based Engineering of Internal Cavities in Coiled-Coil Peptides. Biochemistry 44, 97239732. 